DOI: 10.20472/IAC.2018.935.039

\author{
PEDRO QUIJIJE ANCHUNDIA \\ UNIVERSIDAD LAICA ELOY ALFARO DE MANABí, Ecuador \\ XAVIER VELEZ ROMERO \\ UNIVERSIDAD LAICA ELOY ALFARO DE MANABI, Ecuador
}

ANIUSKA ORTIZ PEREZ

UNIVERSIDAD DE HOLGUIN, Cuba

\title{
RISK MANAGEMENT AND PROCESS MANAGEMENT IN UNIVERSITIES. APPLICATION IN THE UNIVERSITY LAICA ELOY ALFARO MANABÍ
}

\begin{abstract}
:
The current environment demands the application of modern approaches to address the implementation of internal control a priority, to contribute to the continuous improvement of the organizations. It is a necessity in the institutions of higher education the improvement of risk management, as an essential component of internal control and the implementation of process management. In this context at the Universidad Laica Eloy Alfaro Manabi, although they have applied innovative tools of control, there is evidence that the risk assessment is not carried out on a regular basis and it is not structured by processes; therefore, the research aims to: develop tools for process management and risk management in the Universidad Laica Eloy Alfaro of Manabi. To comply with the proposed objective, it starts with the diagnosis of the current situation, through the implementation and analysis of a list of checks that assesses the ability of the organization's strategic prevention, which was adapted to the context of the universities. As the main diagnostic results, an analysis of the gaps and opportunities for improvement in the different variables that make up the dimensions of the design of the strategic orientation and preparation of the university for the management of risks, risk management in an integrated manner, and implementation and control; and then propose tools for process management and risk management. The study used empirical methods and statistical methods, such as the descriptive statistics and Cronbach's Alpha coefficient to measure the reliability of the instrument applied.
\end{abstract}

\section{Keywords:}

Institutions of higher education, university management, internal control, risk management, process management

JEL Classification: 123, M10 


\section{Introduction}

The management as a discipline comes because of own development of society and the changes that have been happening in the business sector, due to the increase in competition and the constant changes in the environment. It is for this reason that has gradually evolved and enriched with new tools, extending its radius of action beyond the business sector, recognized today by different authors in the national and international universities as a management object (Ortiz, 2014).

Ortiz Perez (2014) defines the university management as the process of planning, organization, implementation, control and improvement of university processes in an integrated manner, to increase its quality, in the pursuit of excellence and the satisfaction of the demands of society (efficiency), through a greater effectiveness in decision-making and rational use of the resources (efficiency).

So that internal control is essential in the universities to increase the efficiency and effectiveness in fulfilling its objectives, risk management one of its essential components, which has been recognized by authors like Bolaños, et al (2014); McGregor, Smith (2017) and Huang (2017).

In this sense it is agreed with Bolaños et al (2014), the Raise, that in organizations risks have been studied with greater emphasis from certain specialties such as: occupational risks, environmental risks, risks related to the quality, financial risks, operational risks, strategic risks, risks and logistical chains, and risks of information technology, among others.

It is considered that there is a lack of an integrated approach, in this sense Bolaños (2011), asserts that all of these risks have as their main characteristic which are analyzed on the basis of the specialty to the respondents and it is necessary to the understanding of risk at the organizational level to contribute to the decision-making process in an integrated way.

That is why in the study, considering the definition of risks set out in Resolution 60/2011 of the Comptroller General of the Republic of Cuba (CGRC), to be the one that corresponds with the proposal that is done in the investigation, in addressing the risks associated with the management of the organization. In this resolution is defined as the risk to the uncertainty of an event that might affect or benefit the achievement of the objectives and goals of the organization (CGRC, 2011).

In this context, in the Ecuadorian universities, it is vital to the implementation of risk management as an approach to address, specifically at the Universidad Laica Eloy Alfaro de Manabí (ULEAM) it is evident that, although there have applied tools for the planning and control, risk assessment is not analyzed periodically and there is structured by processes. On the other hand, increasingly the success of organizations depends on the efficient and effective management of its processes, which is recognized by authors such as Pourshahid, et al (2009); Kramer, Wegner (2009); Ortiz, et al (2015); Fuller, et al (2017); Jalali, et al (2017).

The research aims as objective to: develop tools for process management and risk management in the Universidad Laica Eloy Alfaro of Manabí. 


\subsection{Proposed Methodology}

In this section develops a methodology for process management and risk management in higher education institutions (HEI), which is an adaptation of the proposals made by Pupo (2016) and Ortiz (2014).

\subsubsection{Conception of the diagnosis}

It is made a diagnosis of the current situation the university with regard to risk management, from a strategic perspective, with the determination of the capacity of strategic prevention through the implementation of the checklist proposed by Bolaños (2014), on the model of strategic management based on risk management for the integration of the system of management of the company (ARISDE) and adapted by Pupo (2016) in the context of the universities.

\section{Step 1: Communication and training}

Communication and training is a cross-sectional stage is a permanent feedback that is essential in the decision-making levels, to achieve the commitment and participation of workers, in order to achieve the objectives planned in the diagnosis.

Next, it is going be necessary to design a work schedule in which it can specify the training activities to develop at each stage of the methodology, as well as the responsible for its implementation.

\section{Step 2: Prepare the conditions for the study}

To create the conditions to make the diagnosis of risk management, with the constitution of the working group, the quality assurance of the conditions of departure and the characterization of the university.

\section{1 and 2.2 Constitution and training of the working group}

To form the working group, based on the criteria set forth by authors such as Hernandez (2010), Comas (2013), Ortiz (2014), for similar studies, it is recommended that the working group should:

- Be staffed by a team of 7 to 15 people, with the participation of the members of the board of directors and a representation of all areas of the university, as well as the leaders of each process and researchers of experience

- ensure diversity of expertise of the members of the team,

- count with people trained in tools, and

- name a head of the working group.

Through brainstorming and group work, and approves the timetable, their initial tasks will be linked to the training of the working group. 


\subsection{Quality assurance of the initial conditions}

It assesses whether there are the necessary conditions to carry out the study, for this we conduct interviews and consultations with experts from all levels of decision-making, if the conditions of departure are not insured, this stage of preparation is extended.

To continue with the implementation of the methodology, it is necessary to perform actions for training: management techniques, management by processes and tools, risk management, and the strategic approach.

\subsection{Characterization of the organization}

One of the vital elements to develop before starting a research project is to characterize the organization object of study, since it enables the familiarization with the peculiarities of this and allows a greater approach to your organizational culture. Some of the items that can be considered for the characterization are a brief historical background, organizational structure and management levels, you must analyze the composition of the template in teaching and non-teaching workers and teachers by category teaching, academic and scientific degree.

\section{Step 3: Application and processing of the check list}

To continue with the analysis of the risk management at the university through the implementation of the checklist-ARISDE model, this step is divided into two tasks: application, and statistical evaluation of the results.

\subsection{Implementation of the Checklist}

The checklist (Table 1) contains 33 questions to assess the status of the university about the strategic management with a focus on prevention of risks.

It applies to a group of experts with specific knowledge and experience about the direction and management of the Organization. To achieve greater effectiveness will perform the following steps:

- Training of the group of experts with respect to the check list of model-ARISDE,

- review of the documentation related to the process of strategic management and risk management in the organization,

- presentation of the results of the review of the documentation in meeting of the expert group,

- in this meeting may also involve members of the board of directors that do not belong to the group of selected experts, and

- Implementation of the checklist to the group of experts (at least 9 experts). 
Table 1: Sample of the check list applied to the diagnosis of risk management in the ULEAM

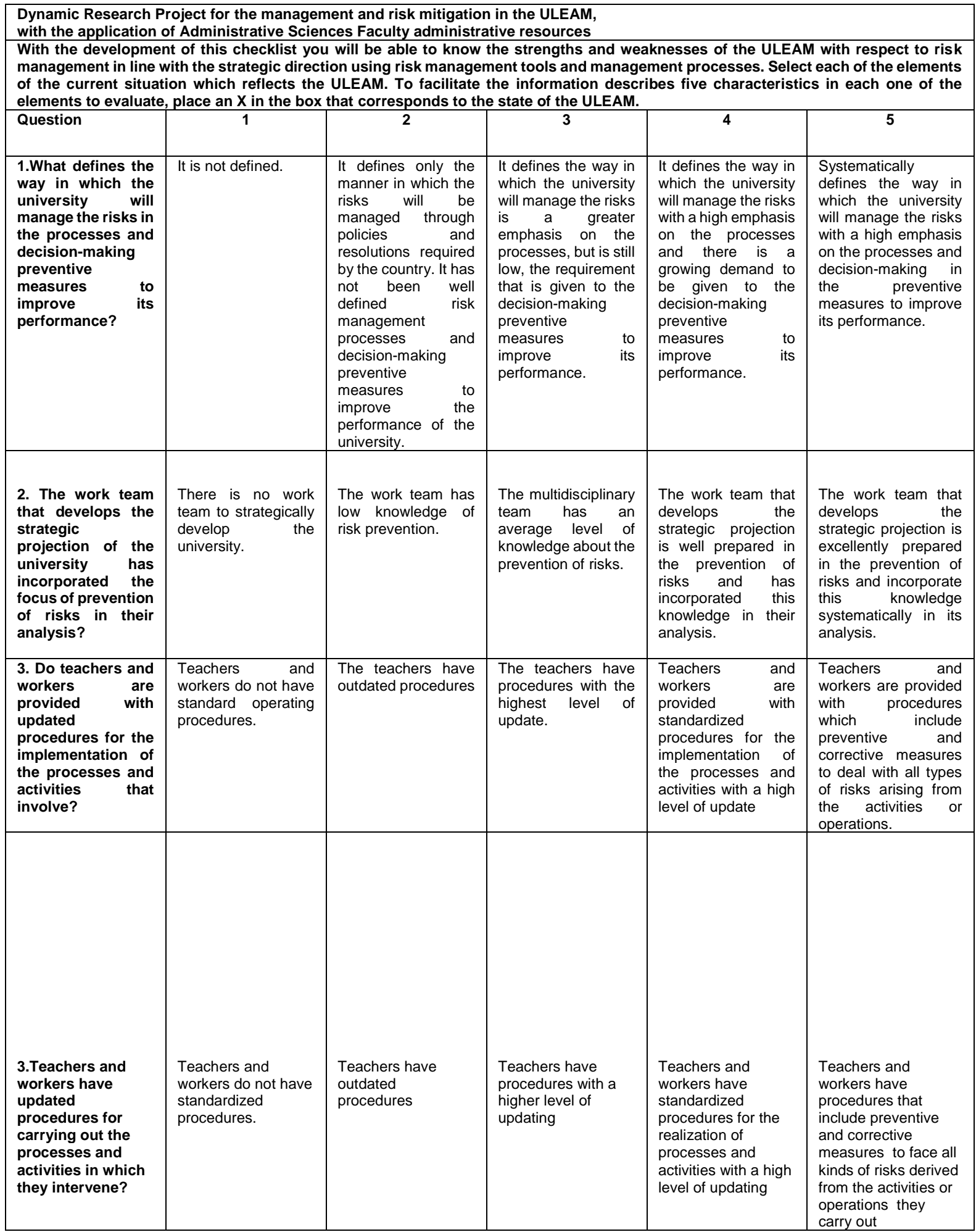

Source: Adapted from Bolaños (2014) and Pupo (2016)

\subsection{Statistical evaluations of the results of the application of the checklist}


For the implementation of this activity at the university, perform the following steps:

- analyze the reliability of the instrument through the Cronbach's alpha, and check that it is greater than 0.7 ,

- obtaining a lower reliability 0.7 can be given for the breach of the conditions explained, in the previous task,

- analyze the results with the use of the descriptive statistics, such as: the average, geometric mean, median, mode, maximum value, minimum value, among others,

- Bolaños Rodríguez (2014), recommends, for the assessment, using the geometric mean of the value given to the questions.

\subsubsection{Design of tools for the management of processes}

It should be started with the review and analysis of all legal documentation, policy and technical regulations, as well as interviews with the principals and teachers of the college experience with the objective of knowing the particularities of the processes and make their description. It is recommended starting with the substantive processes and then continue with the support and strategic. The specific maps of each process are made, the cards, displays and flowcharts are elaborated (Ortiz, 2014).

\section{Step 1: Preparation of the specific map of the process}

The objective of the specific maps is to show the interrelations that are established between the sub processes of the process that is analyzed, for them the following steps are carried out (Ortiz, 2014)

1. The inputs and outputs of the process are identified

2. Sub processes are identified

3. The relationships between the sub processes and their address are established

4. The process is represented

\section{Step 2: Elaborate the process records}

The process cards are designed in the organization according to their needs, so the elements identified for their conformation were defined in correspondence with the particularities of the university, as shown in table 2. In addition to the general files of each process the sub processes files are elaborated for a better organization and understanding of this. 
Table 2: Model of processes records

\begin{tabular}{|l|l|}
\hline Logo and identifier of the University & Name of the process \\
\hline Responsible: & Objectives: \\
\hline Sub processes & \\
\hline Legal Documents, policy and technical: & \\
\hline Check In: & Check Out: \\
\hline Suppliers: & Customers: \\
\hline Process Description: & Reviewed by: \\
\hline Records generated: & Date: \\
\hline Risks of the process: & \\
\hline Relationships with other processes: & \\
\hline Indicators: & \\
\hline Prepared by: & \\
\hline Date: & \\
\hline
\end{tabular}

Source: Ortiz (2014)

For the design of the tabs Ortiz (2014) proposes the following steps:

1. Identify the elements that make up the Processes records

2. Identify the risks.

3. Define indicators.

4. Establish relationships with other processes.

\section{Step 3: Deployment of the processes}

In this step is done for the deployment of the processes of the university, it is considered that it is essential for managers, to be a detailed description of the processes of the organization. In Table 3 is shown a model of deployment of process and elements that contain (Ortiz, 2014). 
Table 3: Model of deployment process

\begin{tabular}{|l|l|l|l|}
\hline Name of the process & Actions & Task \\
\hline Sub processes & Activities & They will be included when \\
\hline $\begin{array}{l}\text { Segments that make up a } \\
\text { process, their identification can } \\
\text { be useful for a better } \\
\text { understanding of these. }\end{array}$ & $\begin{array}{l}\text { Set interrelated tasks and in } \\
\text { order to obtain a specific result. }\end{array}$ & $\begin{array}{l}\text { Non-ordained steps } \\
\text { make up the activities. }\end{array}$ & $\begin{array}{l}\text { They required to detail each task. } \\
\text { red }\end{array}$ \\
\hline
\end{tabular}

Source: Ortiz (2014)

\section{Step 4: Preparation of the Process Flowchart}

The flowchart of processes is a tool widely used in organizations, defined as a schematic picture of this, for making you perform the following steps:

1. Establish the sequence of activities that are part of the process.

2. Define the inputs of each activity and the records that are generated.

3. Link each activity with the responsible for its implementation.

4. Represent graphically the flowchart, using the symbols.

\section{Step 5: Scheduling of processes}

The scheduling of processes is a fundamental tool for the organization of the work of the directors, since it appears to be all over the flow of information that is generated, the model to make the scheduling is shown in table 4, and the steps for your design are the following (Ortiz, 2014):

1. The information that is generated in the development of each process.

2. It sorts the information in the time in which it is emitted.

3. You assign the level and the level it receives.

Table 4: Model of scheduling information

\begin{tabular}{|c|c|c|c|c|c|c|c|c|c|c|c|c|c|c|c|c|}
\hline \multicolumn{17}{|c|}{ Name of the process } \\
\hline \multirow{2}{*}{ No } & \multirow{2}{*}{$\begin{array}{l}\text { Information } \\
\text { deliver }\end{array}$} & & \multicolumn{12}{|c|}{ Month in which information will be delivered } & \multirow{2}{*}{$\begin{array}{l}\text { Level that } \\
\text { informs }\end{array}$} & \multirow{2}{*}{ Level that } \\
\hline & & & $\mathbf{E}$ & $\mathbf{F}$ & $\mathbf{M}$ & $\mathbf{A}$ & $M$ & $\mathbf{J}$ & J & A & $\mathbf{S}$ & 0 & $\mathbf{N}$ & D & & \\
\hline \multicolumn{17}{|l|}{1} \\
\hline \multicolumn{17}{|l|}{2} \\
\hline \multicolumn{17}{|l|}{3} \\
\hline $\mathrm{n}$ & & & & & & & & & & & & & & & & \\
\hline
\end{tabular}

Source: Ortiz (2014) 


\subsubsection{Tools for risk management}

\section{Step 1: qualitative assessment of the risks}

At this stage to follow the steps proposed by Ortiz (2014) for the elaboration of the plan of prevention of risks. The inventory of the existing risks in the different areas of the university. The vice-rectors, deans and heads of area must identify the risks that might affect the achievement of the objectives and goals of the organization in the processes that drive, whether substantive, strategic or support.

To make the qualitative assessment of the risks you must consider the frequency (rare, frequent and moderate) and the impact (catastrophic, severe, moderate and mild).

\section{Step 2: Risk Map}

It is plotted on the $y$-axis and the impact of the $X$ the frequency and priorities are established, considering that:

- are high priority risks that its impact is catastrophic or serious,

- medium priority that its impact is moderate,

- low-those who have a mild impact, and

- within these categories have priority those risks whose probability of occurrence is frequent.

\section{Step 3: Plan for the prevention of risks}

The risk prevention plan is a working tool to provide systematic follow-up to the control objectives and is updated periodically with the active participation of the workers and in the presence of facts which so require. For your clothing identifies the risks, possible negative manifestations; measures to be applied; responsible; performer and date of implementation of the measures.

\subsection{Application in the Universidad Laica Eloy Alfaro Manabí}

Next, it shows the main results of the diagnosis in the ULEAM on risk management, and the implementation of risk-management tools and process management. These results are part of the research developed in the project: dynamic risk management and mitigation in the ULEAM, with the application of administrative resources.

\subsubsection{Diagnosis of risk management at the Universidad Laica Eloy Alfaro Manabí Communication and training}

The communication and training are achieved through actions that are developed during the development of the project, the fundamental rights that were made were the following:

- exchange workshops with the authorities of the university, to socialize the components and objectives of the project, 
- approval of the list of checked by the university authorities, teachers and students linked to the project, and

- exchanges with the Central department of organization and methods, the Central Investigation Department, and the Central Department of Internal Evaluation.

\section{Preparing the conditions for the study}

Ensured the starting conditions for the application of the methodology, training activities were conducted to authorities, teachers and students on the management by processes and risk management in universities. Then he proceeded to characterize the ULEAM, which was created by Law No. 10 published in the Official Gazette No. 313 of November 13 of 1985, is an academic community of higher education, with its own legal status, public, non-profit, academic autonomy, administrative, financial and organizational, pluralistic, critical, scientific and research. It is governed by the Constitution of the Republic of Ecuador, the Higher Education Act, its regulations, the regulations issued by the Council on Higher Education (ESC) and the institution, resolutions and agreements of its collegiate bodies and of its first executive authority.

The ULEAM, is in Manabí Province of the national planning 4 Area of Ecuador. Its campus is divided into the array and three extensions: in the Carmen, the Bahía de Caráquez and Chone. Has adopted an organizational structure represented by the rector and two vice presidents (vice chancellor of academic management and administrative vice president) and the integrated 20 faculties. The mission expresses: The Universidad Laica Eloy Alfaro Manabí, is an institution committed invariably with the search for the truth, the defense of democracy and the rule of law, the scientific and technological research, culture and the link with the community, to contribute within the scope of its powers to a sustained and sustainable human development; providing a learning scientific, technological and humanistic with moral and ethical foundation, which forms human resources that contribute decisively to the improvement of the conditions of life and the wellbeing of manabitas and Ecuadorians. And the vision expresses: The Universidad Laica Eloy Alfaro Manabí aspires to be a modern higher education institution, with a vision for the future, which seeks to be a leader in its field of action, training professionals with a level of scientific knowledge, investigative practices, with social solidarity in whose work the predominant moral and human values, to contribute to their capacity and active participation to the socio-economic development of Manabí and the country.

\section{Application and processing of the check list}

For the diagnosis of risk management in the ULEAM, were selected nine experts in the different levels of decision-making. In the same way interviews and exchanges with the university authorities, which includes the following areas: Academic, Administrative Vice-chancellorship Vicechancellorship, Central Investigation Department, Central Department of Organization and Methods, Internal Evaluation Department, Faculty of Management, and Faculty of Accounting and Auditing. With the use of the SPSS statistical software was checked the reliability of the instrument 
through the Cronbach alpha coefficient of 0.9 , so it can be said that the instrument is reliable. The results of the application of the checklist are shown in table 5.

\section{Table 5: Results of the application of the checklist}

\begin{tabular}{|c|c|c|c|c|c|c|c|c|c|c|}
\hline Expert/ Questions & E1 & E2 & E3 & E4 & E5 & E6 & E7 & E8 & E9 & Each question average \\
\hline P1 & 1 & 2 & 4 & 2 & 2 & 3 & 1 & 2 & 3 & 2,03 \\
\hline P2 & 1 & 2 & 4 & 1 & 1 & 2 & 2 & 2 & 3 & 1,79 \\
\hline P3 & 2 & 2 & 4 & 3 & 3 & 3 & 3 & 3 & 2 & 2,71 \\
\hline P4 & 3 & 2 & 3 & 3 & 3 & 3 & 3 & 3 & 2 & 2,74 \\
\hline P5 & 3 & 3 & 3 & 3 & 3 & 4 & 4 & 2 & 2 & 2,92 \\
\hline P6 & 2 & 3 & 4 & 1 & 4 & 4 & 4 & 1 & 1 & 2,26 \\
\hline P7 & 3 & 4 & 4 & 3 & 3 & 4 & 3 & 3 & 3 & 3,30 \\
\hline P8 & 2 & 3 & 3 & 3 & 3 & 3 & 4 & 1 & 2 & 2,51 \\
\hline P9 & 2 & 2 & 3 & 2 & 3 & 3 & 1 & 1 & 2 & 1,96 \\
\hline P10 & 1 & 1 & 3 & 1 & 1 & 1 & 1 & 1 & 2 & 1,22 \\
\hline P11 & 2 & 2 & 3 & 1 & 2 & 3 & 2 & 1 & 2 & 1,88 \\
\hline P12 & 2 & 3 & 3 & 1 & 1 & 3 & 1 & 1 & 2 & 1,68 \\
\hline P13 & 2 & 3 & 3 & 2 & 2 & 3 & 1 & 1 & 2 & 1,96 \\
\hline P14 & 1 & 2 & 3 & 2 & 2 & 2 & 1 & 1 & 2 & 1,66 \\
\hline P15 & 2 & 3 & 3 & 2 & 2 & 2 & 1 & 2 & 2 & 2,03 \\
\hline P16 & 2 & 3 & 3 & 1 & 1 & 3 & 1 & 2 & 3 & 1,90 \\
\hline P17 & 2 & 2 & 3 & 1 & 2 & 3 & 1 & 2 & 3 & 1,96 \\
\hline P18 & 2 & 3 & 3 & 2 & 3 & 3 & 1 & 2 & 4 & 2,39 \\
\hline P19 & 2 & 3 & 3 & 2 & 2 & 3 & 1 & 1 & 2 & 1,96 \\
\hline P20 & 1 & 2 & 3 & 1 & 2 & 2 & 1 & 1 & 3 & 1,61 \\
\hline P21 & 2 & 2 & 3 & 3 & 3 & 3 & 3 & 1 & 2 & 2,32 \\
\hline P22 & 2 & 3 & 3 & 3 & 3 & 3 & 1 & 1 & 2 & 2,15 \\
\hline P23 & 2 & 3 & 3 & 3 & 3 & 3 & 4 & 1 & 2 & 2,51 \\
\hline P24 & 2 & 2 & 3 & 3 & 4 & 4 & 4 & 2 & 2 & 2,76 \\
\hline P25 & 2 & 3 & 3 & 2 & 3 & 3 & 3 & 2 & 2 & 2,51 \\
\hline P26 & 2 & 2 & 3 & 3 & 4 & 4 & 3 & 1 & 2 & 2,47 \\
\hline P27 & 2 & 2 & 3 & 3 & 3 & 4 & 3 & 1 & 2 & 2,39 \\
\hline P28 & 2 & 2 & 3 & 2 & 2 & 2 & 1 & 2 & 1 & 1,79 \\
\hline P29 & 2 & 2 & 3 & 3 & 3 & 3 & 1 & 2 & 2 & 2,22 \\
\hline P30 & 2 & 3 & 3 & 3 & 3 & 3 & 3 & 1 & 2 & 2,43 \\
\hline P31 & 2 & 2 & 3 & 2 & 3 & 3 & 3 & 1 & 3 & 2,32 \\
\hline P32 & 2 & 2 & 4 & 3 & 4 & 4 & 3 & 1 & 3 & 2,67 \\
\hline P33 & 2 & 3 & 3 & 2 & 2 & 2 & 2 & 2 & 2 & 2,19 \\
\hline
\end{tabular}

Source: Results of a research project for the management and mitigation of risks in the ULEAM, with the application of administrative resources

With the implementation of the checklist are obtained the gaps that presents the university with respect to the capacity of strategic prevention. Using the geometric mean of the answer from the experts in each question on the checklist and the analysis is performed. In the table 6 shows the evaluation of the variables and dimensions.

Table 6: Evaluation of the variables and dimensions of the checklist

\begin{tabular}{|c|c|c|c|c|c|c|}
\hline $\begin{array}{l}\text { Experts/ } \\
\text { Questions }\end{array}$ & $\begin{array}{c}\text { Each } \\
\text { Question } \\
\text { variable }\end{array}$ & & MG & Dimension & MG & CAPE \\
\hline $\mathrm{P} 1$ & 1,92 & \multirow{2}{*}{ Trained team } & \multirow{2}{*}{1,91} & \multirow{8}{*}{$\begin{array}{c}\text { Design Team } \\
\text { manager of the } \\
\text { strategic orientation } \\
\text { and preparation of the } \\
\text { university for the risk } \\
\text { management }\end{array}$} & \multirow{8}{*}{2,27} & \multirow{8}{*}{2,23} \\
\hline $\mathrm{P} 2$ & 1,64 & & & & & \\
\hline P3 & 2,78 & \multirow{2}{*}{ Prepared workers } & \multirow{2}{*}{2,72} & & & \\
\hline $\mathrm{P} 4$ & 2,83 & & & & & \\
\hline P5 & 3,26 & \multirow[t]{4}{*}{ Strategic direction } & \multirow{4}{*}{2,25} & & & \\
\hline P6 & 2,85 & & & & & \\
\hline P7 & 3,39 & & & & & \\
\hline P8 & 2,95 & & & & & \\
\hline
\end{tabular}




\begin{tabular}{|c|c|c|c|c|c|}
\hline P9 & 2,16 & Preparing the & & & \\
\hline P10 & 1,17 & management & & & \\
\hline $\mathrm{P} 11$ & 2,03 & \multirow{4}{*}{$\begin{array}{l}\text { Diagnosis of risks by } \\
\text { processes }\end{array}$} & \multirow{4}{*}{1,79} & \multirow{13}{*}{$\begin{array}{l}\text { Risk management in } \\
\text { an integrated manner }\end{array}$} & \multirow{13}{*}{2,01} \\
\hline P12 & 1,77 & & & & \\
\hline P13 & 2,16 & & & & \\
\hline P14 & 1,74 & & & & \\
\hline P15 & 2,03 & \multirow{5}{*}{ Integrated risk analysis } & \multirow{5}{*}{2,04} & & \\
\hline P16 & 1,77 & & & & \\
\hline P17 & 1,84 & & & & \\
\hline P18 & 2,28 & & & & \\
\hline P19 & 2,16 & & & & \\
\hline P20 & 1,57 & \multirow{2}{*}{ Risk strategies } & \multirow{2}{*}{1,93} & & \\
\hline P21 & 2,67 & & & & \\
\hline P22 & 2,42 & \multirow[t]{2}{*}{ Strategic action program } & \multirow{2}{*}{2,32} & & \\
\hline P23 & 2,95 & & & & \\
\hline P24 & 3,02 & \multirow{2}{*}{$\begin{array}{l}\text { Information and } \\
\text { communication }\end{array}$} & \multirow{2}{*}{2,63} & \multirow{10}{*}{$\begin{array}{l}\text { Implementation and } \\
\text { control }\end{array}$} & \multirow{10}{*}{2,41} \\
\hline P25 & 2,67 & & & & \\
\hline P26 & 2,90 & \multirow{5}{*}{$\begin{array}{l}\text { Implementation of } \\
\text { strategic actions }\end{array}$} & \multirow{5}{*}{2,25} & & \\
\hline P27 & 2,78 & & & & \\
\hline P28 & 1,92 & & & & \\
\hline P29 & 2,28 & & & & \\
\hline P30 & 2,83 & & & & \\
\hline P31 & 2,52 & \multirow{3}{*}{$\begin{array}{l}\text { Evaluation and control } \\
\text { review }\end{array}$} & \multirow{3}{*}{2,38} & & \\
\hline P32 & 3,02 & & & & \\
\hline P33 & 2,25 & & & & \\
\hline
\end{tabular}

Source: Results of a research project for the dynamic risk management and mitigation in the ULEAM, with the application of administrative resources.

In a general sense, the lowest score questions are related to the variables: diagnosis of risks by processes, integrated risk analysis, strategic action program, information and communication, implementation of the strategic actions, and review, evaluation and control. The results of the implementation of the checklist and interviews with the authorities, professors and students of the ULEAM, it is concluded that:

In the design of the strategic orientation and preparation of the university for the administration of risks (Figure 1), the team that develops the strategic projection of the university has not defined the way to manage the risks of processes for decision-making preventive measures and improve performance, as a result, there is a system of information related to the management of risks.

About the dimension of risk management in an integrated way (Figure 2), are not identified the risks in an integrated manner in the processes of the university, or of the causes that influence, which does not allow you to make your measurement and qualitative assessment. In the same way does not determine the risks that most affect the coordination between processes (internal relations) and of these with external entities, this limits the identification of key risks that affect the performance of the university. 
In the dimension implementation and control (Figure 3), there is a system of management indicators that contribute to effective decision-making, which has not allowed to ensure that the risks of having a greater impact on the university should be managed with integral actions.

Figure 1: Results in the dimension of design, strategic guidance and preparation of the university for the risk management

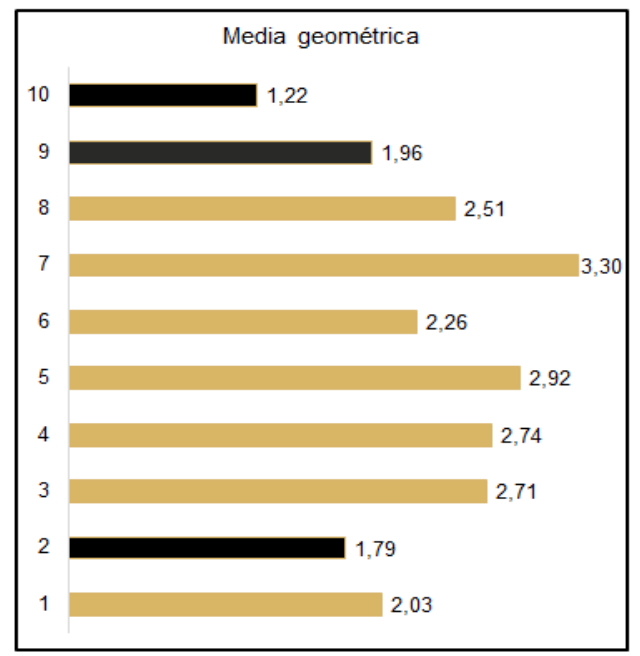

Source: Results of a research project for the management and mitigation of risks in the ULEAM, with the application of administrative resources

Figure 2: Results in the risk management dimension in an integrated manner

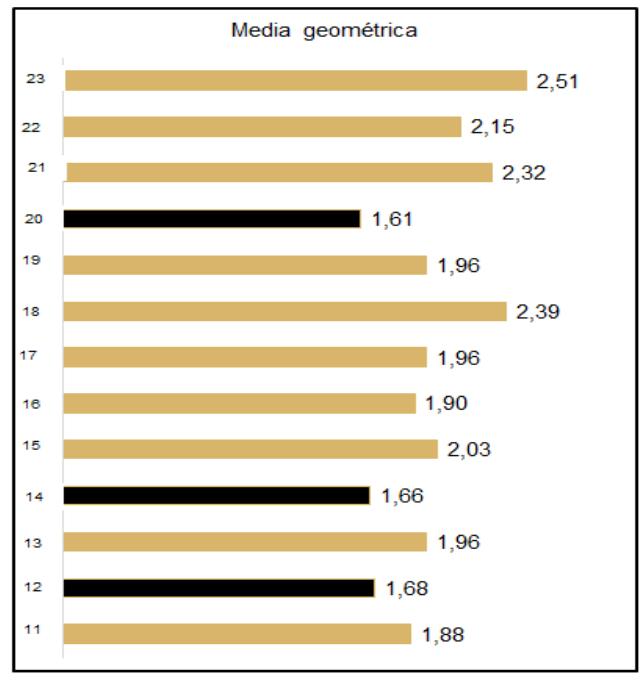

Source: Results of a research project for the dynamic risk management and mitigation in the ULEAM, with the application of administrative resources. 
Figure 3: Results in the implementation and control dimension

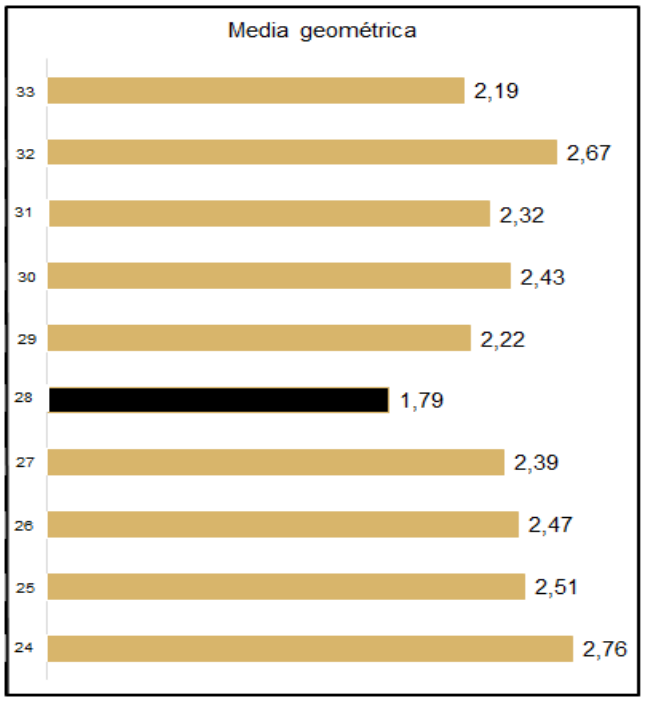

Source: Results of a research project for the dynamic risk management and mitigation in the ULEAM, with the application of administrative resources.

\subsubsection{Application of the tools for risk management and the management by processes in the Universidad Laica Eloy Alfaro Manabí}

As follows, it is presented the results of the application of these tools in the process of academic management, in figure 4 shows an example of a part of the tab in this process.

\section{Figure 4: The process of academic management (sample)}

\begin{tabular}{|c|c|}
\hline & $\begin{array}{l}\text { Process record } \\
\text { Academic management }\end{array}$ \\
\hline \multicolumn{2}{|c|}{ Responsibility: Vice-rector for Academic Management } \\
\hline \multicolumn{2}{|c|}{$\begin{array}{l}\text { Objective: To train competent professionals to perform successfully in the various sectors of the economy and society in general. } \\
\text { Thread: methodological work, teaching work, Admission, Retention, Graduation, Certification }\end{array}$} \\
\hline \multicolumn{2}{|c|}{$\begin{array}{l}\text { Documents Legal, regulatory and technical: } \\
\text { - Articles } 3 \text { and } 350 \text { of the Constitution of the Republic of Ecuador. } \\
\text { - Higher Education Act } \\
\text { - Article } 5 \text {, Section b, of the Higher Education Act } \\
\text { - Model for the evaluation and accreditation of institutions and of the Council of Assessment, Accreditation and Quality Assurance of } \\
\text { the Quality of Higher Education } \\
\text { - Academic Rules of the ULEAM } \\
\text { - Article } 15 \text { of the Rules of Procedure of the academic regime } \\
\text { - Article } 19 \text { of the Rules of Procedure of the academic regime } \\
\text { other... }\end{array}$} \\
\hline \multicolumn{2}{|c|}{$\begin{array}{l}\text { Entries: } \\
\text { - Students } \\
\text { - Teachers } \\
\text { - material and financial resources } \\
\text { * Rectories and Ministerial Resolutions, and other policy documents and technical } \\
\text { information }\end{array}$} \\
\hline Providers: & \\
\hline
\end{tabular}




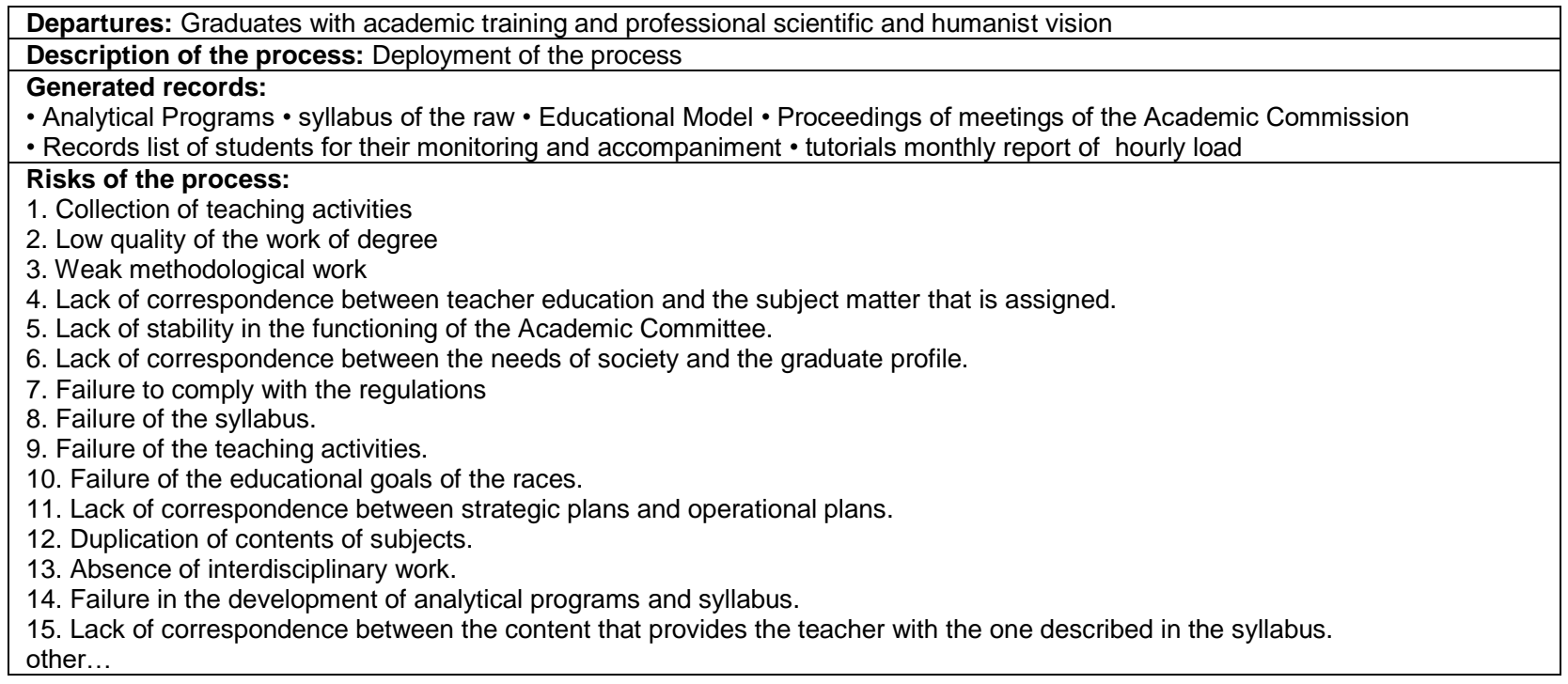

Source: Results of a research project for the dynamic risk management and mitigation in the ULEAM, with the application of administrative resources

In Figure 5 displays the map of risks, establishing priorities based on the frequency and impact.

\section{Figure 5: Map of risks in the process of academic management ULEAM (sample)}

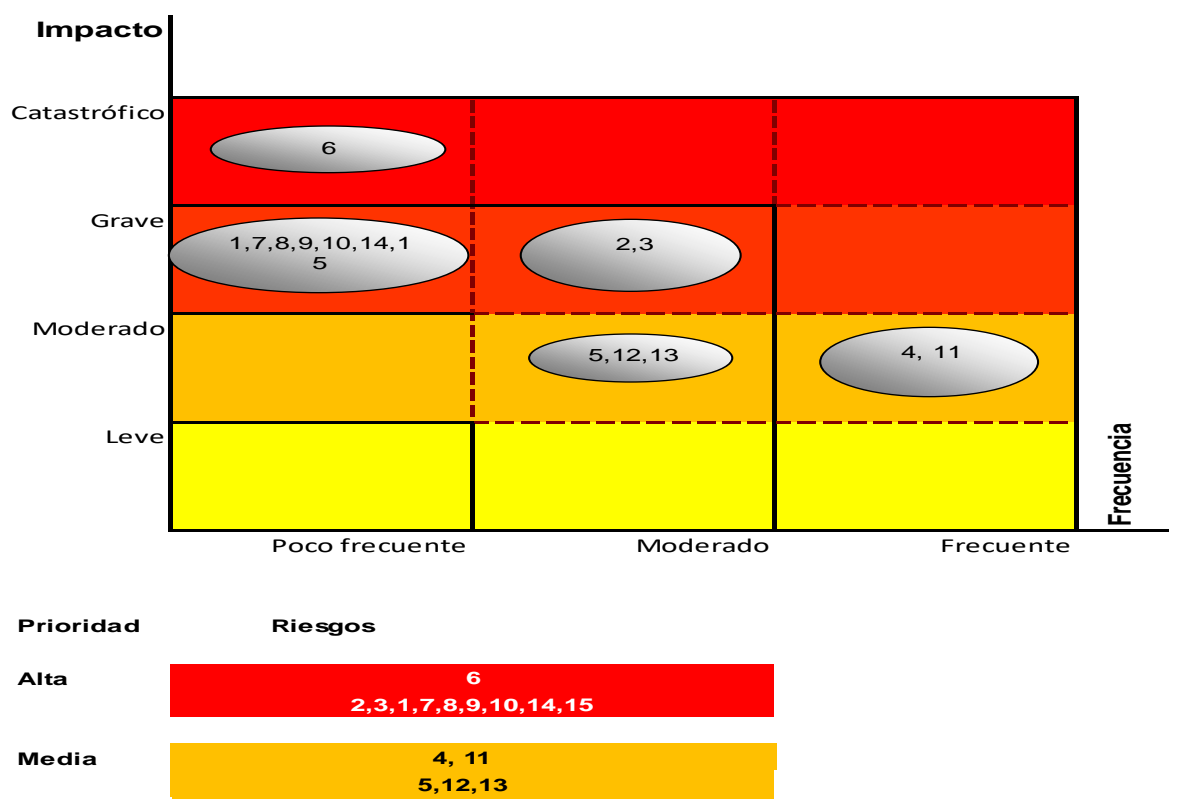

Source: Results of a research project for the dynamic risk management and mitigation in the ULEAM, with the application of administrative resources.

After the culmination of the previous steps, the preparation of the risk prevention plan is preceded as it is shown in the figure 6. 
Figure 6: Plan of prevention of the process of academic management of the ULEAM (example)

\section{PREVENTION PLAN}

Methodological work subprocess

\begin{tabular}{|c|c|c|c|c|c|}
\hline Risk & Negative Manifestation & Measures to talke & Responsible & Execute & Due date \\
\hline $\begin{array}{l}\text { Lack of } \\
\text { correspondence } \\
\text { between teacher } \\
\text { training and the } \\
\text { assigned chair }\end{array}$ & $\begin{array}{l}\text { - The academic potential } \\
\text { of the teacher is not } \\
\text { used in correspondence } \\
\text { with his specialty } \\
\text { - Insufficient knowledge } \\
\text { of the teacher to impart } \\
\text { with quality the subject } \\
\text { assigned to him }\end{array}$ & $\begin{array}{l}\text { - Determination of the } \\
\text { profile of the chair. } \\
\text { - Review of professional } \\
\text { profile and profile of the } \\
\text { chair } \\
\text { - Assign the chair in } \\
\text { correspondence with the } \\
\text { academic formation of } \\
\text { the professor }\end{array}$ & $\begin{array}{l}\text { - Academic vice- } \\
\text { rectorate } \\
\text { - Dean of each } \\
\text { faculty }\end{array}$ & $\begin{array}{l}\text { Academic vice- } \\
\text { rectorate } \\
\text { - Academic Career } \\
\text { Commission }\end{array}$ & $\begin{array}{l}\text {-six months } \\
\text { - two months } \\
\text { before the start of } \\
\text { each academic } \\
\text { period }\end{array}$ \\
\hline
\end{tabular}

Source: Results of a research project for the dynamic risk management and mitigation in the ULEAM, with the application of administrative resources.

\section{Conclusions}

The consultation of updated bibliography on risk management allowed to corroborate the importance of this management approach for the achievement of the strategic objectives of the universities and their relevance to increase the effectiveness in the management of the IES.

The implementation of process management and risk management in IES is essential for the comprehension of university as a system, increasing the satisfaction of the demands of the company and continuous quality improvement.

The sequence of steps proposed to perform the diagnosis of risk management in universities, constitute a methodological guide, which helps to improve the strategic plan and achieve greater effectiveness in meeting the objectives, when performing integrated analysis of the university.

The set of proposed tools, among which is the process map, the card, the deployment, the risk map, and the prevention plan, provide managers with a methodological tool that contributes to increasing efficiency and effectiveness in the management of processes.

The application of the checklist proposed by Bolaños Rodriguez (2014) and adapted to the characteristics of the ULEAM to carry out the diagnosis, allowed to confirm that there are inadequacies and opportunities for improvement in the dimensions of: orientation, strategy and 
preparation design of the university for risk management, integrated risk management, and implementation and control.

As main results in the ULEAM, we obtain: the documentation of the academic management process, and the proposal of a set of tools for risk management that contributes to raising the quality of the institution and its level of accreditation.

\section{References}

BOLAÑO RODRÍGUEZ, Y. (2014). Modelo de dirección estratégica basado en la administración de riesgos para la integración del sistema de dirección de la empresa. Tesis presentada en opción al grado científico de Doctor en Ciencias Técnicas, Instituto Superior Politécnico José Antonio Echeverría, La Habana.

BOLAÑO RODRÍGUEZ, Y.; ALFONSO ROBAINA, D.; PÉREZ BARNÉS, A. and ARIAS PÉREZ, M. (2014). Modelo de Dirección Estratégica basado en la Administración de Riesgos. Ingeniería Industrial. 2014, Vol. XXXV, No. 3, s. 344-357.

BOLAÑO RODRÍGUEZ, Y.; ALFONSO ROBAINA, D.; RAMÍREZ MOROII, A. and HERNÁNDEZ RODRÍGUEZ, A. A. (2011). Modelo de identificación, medición, evaluación de riesgos para la dirección estratégica. Ingeniería Industrial. 2011, Vol. XXXII, No. 2, s. 162-169.

COMAS RODRÍGUEZ, R. (2013). Integración de herramientas de control de gestión para el alineamiento estratégico en el sistema empresarial cubano. Aplicación en empresas de Sancti Spiritus. Tesis presentada en opción al grado científico de Doctor en Ciencias Técnicas, Universidad de Matanzas Camilo Cienfuegos, Matanzas.

CONTRALORÍA GENERAL DE LA REPÚBLICA DE CUBA. (2011). Resolución No. 60 Normas del Sistema de Control Interno. Gaceta oficial de la República, CIX (13), 39-50.

FULLER, C.W.; FULLER, G.W. and KEMP, S.P.T. (2017). Evaluation of World Rugby's concussion management process: results from Rugby World Cup 2015. British Journal of Sports Medicine, 2017, Vol. 51, No. 1, s. 903-925.

HERNÁNDEZ NARIÑO, A. (2010). Contribución a la gestión y mejora de procesos en instalaciones hospitalarias del territorio matancero. Tesis presentada en opción al grado científico de Doctor en Ciencias Técnicas, Universidad de Matanzas Camilo Cienfuegos, Matanzas.

HUANG, J. (2017). Discussion on Risk Management and Value Driven Control Mode. Electric Power Information and Communication Technology, 2017, Vol, 15, No. 8, s. 104-111.

KRAMER, S. and WEGNER, H. (2009). Online analysis improves process management. Nachrichten Aus Der Chemie, 2009, Vol. 57, No. 4, s, 434-445.

MCGREGOR, A. and SMIT, J. (2017). Risk management: Human rights due diligence in corporate global supply chains. Governance Directions, 2017, Vol. 69, No. 1, s. 16-21. 
ÓRGANO COLEGIADO ACADÉMICO SUPERIOR DE LA UNIVERSIDAD LAICA ELOY ALFARO DE MANABÍ. (2014). Reformas al estatuto declaración de principios y base legal. Universidada Laica Eloy Alfaro de Manabí.

ORTIZ PÉREZ, A. (2014). Tecnología para la gestión integrada de los procesos en universidades. Aplicación en la Universidad de Holguín. Tesis presentada en opción al grado científico de Doctor en Ciencias Técnicas, Universidad de Holguín Oscar Lucero Moya, Holguín.

ORTIZ PÉREZ, A.; FUNZY CHIMPOLO, J. M.; PÉREZ CAMPAÑA, M. and VELÁZQUEZ ZALDÍVAR, R. (2015). La gestión integrada de los procesos en universidades. Procedimiento para su evaluación. Revista Ingeniería Industrial, 2015, Vol. XXXVI, No. 1, s. 91-103.

POURSHAHID, A.; AMYOT, D.; PEYTON, L.; GHANAVATI, S.; CHEN, P. F., WEISS, M. and FORSTER, A. J. (2009). Business process management with the user requirements notation. Electronic Commerce Research, 2009, Vol. 9, No. 4, s. 269-316.

PUPO PÉREZ, A. (2016). Procedimiento para la gestión y prevención de riesgos en universidades. Aplicación en la Universidad de Holguín. Tesis presentada en opción al título de Ingeniero Industrial, Universidad de Holguín, Holguín. 